\title{
Competitiveness of the Slovak Republic as a Determinant of its Success in Third Country Markets
}

\author{
Stanislav Zábojník ${ }^{1 *}$, and Zuzana Borovská \\ ${ }^{1}$ Assoc. Professor, PhD. University of Economics in Bratislava, Faculty of Commerce, Department of \\ International Trade, Dolnozemská cesta 1, 85235 Bratislava, Slovakia \\ ${ }^{1}$ internal PhD. Student, University of Economics in Bratislava, Faculty of Commerce, Department of \\ International Trade, Dolnozemská cesta 1,852 35 Bratislava, Slovakia
}

\begin{abstract}
.
Research background: Despite long-term goals of the economic strategy of the Slovak Republic, the Slovak competitiveness on the third countries' markets is relatively weak considering the long tradition in the export activities of the Czechoslovak companies in the past. In terms of the international trade orientation, we note that the method of the Slovak economic strategy is mainly the pro-export support and placement of the Slovak production on foreign markets. Given the openness of the Slovak economy, competitiveness within these markets is crucial and proves the relevance of the research. Slovak Strategy of the External Economic Relations defines two groups of the priority territories for the support and subsidizing of the Slovak exports.

Purpose of the article: The paper assesses the results of the strategy supporting the Slovak companies on the third markets and an aim of the paper is to define the key indicators of the competitiveness of the Slovak Republic on the third markets of the prioritized territories.

Methods: Authors use basic indicators (export volumes, market share, RCA) as well as export gap method.

Findings \& Value added: The study indicates only a very small progress in the catching-up process of the Slovak companies in case of export competitiveness in the preferential territories outside of the EU. A comprehensive comparison of the V4 countries was realized and recommendations for a new strategy were formulated.
\end{abstract}

Keywords: competitiveness; export; non-eu trade; pro-export policy

JEL Classification: $F 10 ; F 13 ; F 60$

${ }^{*}$ Corresponding author: stanislav.zabojnik@euba.sk 


\section{Introduction}

The performance of the Slovak Republic in the area of foreign trade has gone through several stages of development, characterized by a relatively high degree of volatility. If after the Second World War the share of Czechoslovakia's exports to the West was about 2/3 of all exports, in 1989 this share was close to about 10\%. This was a clear manifestation not only of the loss of markets, but also of the inability to produce competitive goods with the appropriate technical-utility properties and a favourable price. The reasons for the long-term lower dynamics of participation in the international division of labour also result from the delayed and slowed down responses of the economy to the development processes that are taking place throughout the world economy. While in the years 1950-1990 world exports increased 58 times, exports of the Czechoslovak Socialist Republic (ČSR) increased only 20 times, from $0.8 \%$ to 15.6 billion. \$. In 1938 , the share of the ČSR in world trade was $2.0 \%$, in 1950 yet $1.3 \%$ and in 1990 it fell to $0.44 \%$. In 1995, despite the ongoing global economic boom, this share was $0.12 \%$ in the Slovak Republic (SR) and in 2002 only $0.08 \%$. The average increase in exports was about $7 \%$ in the four mentioned decades, which was $3 \%$ less than the average increase in world trade.

Adequate with the political barriers and the above-mentioned changes in the volume of foreign trade of the SR, the structure of its most important trading partners was also reflected. The territorial structure of foreign trade of the SR has undergone a fundamental transformation since the division. The strategic document which had to stimulate Slovak companies (especially small and medium-sized enterprises - SMEs) from 2013 was called the Strategy of External Economic Relations, which conceived both the long-term goals of the structure of foreign trade of the SR and specific instruments for its fulfilment. The third country markets, which were included in these strategic objectives through countries of priority importance, had a specific position in the objectives and instruments of this document. Slovak Strategy of the External Economic Relations defines two groups of the priority territories for the support and subsidizing of the Slovak exports. Due to insufficient results, these groups were continuously slightly adjusted, especially for the application of specific Export-Import Bank of Slovak Republic (EXIMBANKA SR) tools.

In September 2020, working group within the Ministry of Economy of the Slovak Republic started to design a new concept of the strategy supporting the Slovak companies (mainly SMEs) on the third markets. The paper should shed the light on the results of the previous strategic document and an effectivity of the support assessing the results achieved by the concept, goals and tools of the initiative.

\section{Literature review and Methodology}

Several authors point to the insufficient performance of Slovak companies, especially SMEs in the foreign trade of the Slovak Republic [3, 18].

To achieve the main goal, authors use a comparison of the major competitiveness indicators such as export volume, basic competitiveness indices and market share. The methodology to identify the export competitiveness on foreign markets differs. According to ITC (2019), Balaz et al. (2015), Ruzekova and Kastakova (2018) and Sterbova (2013), basic approaches comprise:

- $\quad$ export volume,

- $\quad$ export growth rate,

- export p.c.,

- net export,

- market share at the global level,

- relative trade balance, 
- $\quad$ Revealed comparative advantage (RCA) - (RCA1, or RCA2),

- Michaely's index,

- Unit labour costs (ULC),

- Real effective exchange rate (REER),

- Terms of trade,

- TiVA parameter,

- $\quad$ the effect of competitiveness $[2,18,20]$.

Several Central and Eastern European (CEE) authors pointed out necessary and vital role of export performance for some CEE economies [17], nevertheless, only few deals with export structure as an analysis filtering the effect of transnational corporations (TNCs) presence decreasing active participation within GVCs and subsequent value-added creation. Among number of distinguished authors, mainly Fojtikova (2016) and Fojtikova and Stancikova (2017) stress the composite indexes as an appropriate methodology to measure the competitiveness in foreign markets [12,13]. According to Bojnec and Fertő (2014), the export competitiveness on third countries' markets should be analysed traditional approach of Balassa's RCA indicator [6]. This study assesses Slovakia as one of the least competitive countries on extra-EU market within specific industries. For further dynamic growth of CEE countries, Benkovskis and Rimgailaite (2011), condition it by export variety of the new EU members [4]. The Slovak exports are the most intensively linked to a common market of the EU, approximately $86 \%$ of Slovak exports are heading to EU27 members. Moreover, domestic value added, share of high-tech exports as well as capital-intensive goods boost export competitiveness. Nevertheless, Carrasco and Tovar-Garcia (2020) pointed out that another three major factors dominate the overall export competitiveness in the long run: export composition, export diversification and import composition [8]. Guillou and Treibich (2019) stress that export diversification on third countries' market invokes necessary organizational and managerial changes [14].

Applying several segments of the EU countries, Fojtikova (2016) proves that it is necessary to assess a dynamic of the comparative advantages by differentiating among new and old members of the EU and smaller and bigger economies within EU, therefore there is no unified recommendation for the export structure optimization [12]. The same author proved the highest export performance dynamics in case of new Eurozone members [11]. Also, Benkovskis et al. (2020) using Bayesian model proved different effect based on the segment of the countries, though, there has been proved one general factor shaping export competitiveness on third countries' markets: competitive pressures from China have strongly affected export performance since the early 2000s [5]. According to authors, labour and total factor productivity are particularly important for the new EU members, while inward FDI rather than domestic investment drives export market share on third countries' market. Surprisingly, price competitiveness does not play a crucial role in case of any EU country. Cieślik et al. (2015) indicated a relationship between the growth of the number of export countries and export performance is initially positive but becomes negative over time [9]. There are several hesitations and professional opinions that such a small country like Slovakia lacks comprehensive third countries' market knowledge and market information. On a specific case of Iran, Hajiha et al. (2009) proved that export market information and export knowledge doesn't affect export performance [15].

Based on economic literature in the field, Slovak strategy also stands on the assumption that higher export diversification brings higher export performance measured as total export to GDP. The basic logic of the policy creation considers substantial concentration of export to a few trade partners and/or commodity items increases vulnerability of national economy to negative extent shock [19]. Nevertheless, more contemporary researches of the Eurozone countries have brought directly opposite results. Del Rosal (2018) proved a positive 
relationship between Spanish export concentration and export performance by destination market [10]. Nevertheless, the aim of the study is to assess one of the major objectives of the Slovak foreign trade policy - export diversification on the extra-EU markets.

A main purpose of the article is to characterise a general assessment of the results within export activities of the Slovak companies penetrating the third countries' markets defined within the Slovak Strategy of the External Economic Relations. To assess overall potential for the Slovak exporters on third countries markets, an export gap approach is applied to identify potential in the third countries' export markets to design more suitable support mechanism for the enterprises. As for the data, time series of the export volumes of the Slovak Republic for the period from 2000 to 2019 were used. Authors also used the Database International Trade Centre (ITC). Firstly, they analyse a dynamic of the export structure of the third countries divided within the first and second group of countries of the priority importance. Secondly, authors use the method of comparison to the CEE (mainly V4 countries) applied on the position of the preferred third countries within the export structure.

Finally, export gap method is applied to characterise an effectivity of the export support to identify the potential export and compare to statistic data for the recent period. This method reflects the assumption that prioritized third country within the Slovak strategy relatively loose the economic performance and their position in the Slovak export structure diminish too. Based on Broncek (2019), the export gap characterising a difference between an export potential and real export volume, the parameter is calculated as following [7]:

$$
E G_{j i k}^{n}=\left(\frac{\sum_{n 0}^{n} \frac{X_{j k}}{M_{w k}}}{(n-n 0)+1}-\frac{X_{j i k}^{n}}{M_{i k}^{n}}\right) M_{i k}^{n}
$$

where:

$E G_{j i k}^{n}$ is the export gap of country $j$ for commodity $k$ exported to country $i$ in year $n$;

$X_{j k}$ is the export of commodity $k$ of country $j$;

$M_{w k}$ is the world import of commodity $k$;

$X_{j i k}^{n}$ is the export of commodity $k$ from country $j$ to country $i$ in year $n$;

$M_{i k}^{n}$ is the import of commodity $k$ of country $j$ in year $n$;

$n \quad$ is the year for which we will calculate the export gap;

$n 0$ is the first year within the interval for which we calculate the average index $\mathrm{RCA}_{\mathrm{jk}}$.

\section{Results}

Having taken into account the specifics of the Slovak foreign trade, assessing the foreign trade structure development up to 2012, the new strategy had been prepared in 2013 to be implemented within the period from 2014 up to 2020. Particularly, the Slovak export is dominated by foreign TNCs' exports to EU common market what is declared by $86.2 \%$ share of the EU countries on the Slovak exports in 2009, slightly decelerating up to $84.3 \%$ in 2019 . Implemented Strategy of external economic relations of the Slovak Republic for the period 2014-2020 stressed export diversification supporting exploration on the third countries' markets using several measures. The most important tools associated with appropriate budget covered are:

- trade policy instruments;

- autonomous instruments to support the export of goods and services,

- contractual instruments to support the export of goods and services, 
- measures to ensure a stable supply of strategic goods,

- investment instruments.

- tools to support innovation cooperation with foreign countries

- tools of unified presentation of the Slovak Republic.

Particular results of the strategy are quite ambiguous. Based on our analysis shown in Table 1, neither the share of the countries in the first nor in the second group of the third countries of the priority importance have increased. As for the research focus of the article, further research was aimed at the two groups of the priority interest:

Group 1: Serbia, Bosnia and Herzegovina, North Macedonia, Turkey, Viet Nam, Indonesia, Cuba, Egypt, India, South Africa, Kenya, Russian Federation, Ukraine, Belarus, Georgia, Azerbaijan, Kazakhstan Tajikistan, Turkmenistan, Uzbekistan, Chile, Brazil, China.

Group 2: Pakistan, Argentina, Iraq, United Arab Emirates, Armenia, Libya.

Dedicated budget and adequate measures were used to meet the goals set within the Strategy, nevertheless, as shown in the Table 1, being almost at the end of the implementation period, the share of the third countries of the priority interested has even diminished.

As for the Slovak export volumes, prioritized third countries within the two groups achieved the peak in 2013, when started to be prioritized, as much as 7,062 mil. $€$ and have faced a decreasing trend since then. Having hit the trough in 2015 with the value of 5,018 mil. $€$, the recent data showed a small return to $100 \$ / \mathrm{bbl}$ era volumes with 5,794 mil. $€$.

Table 1. Dynamics of the third countries' market shares on Slovak export.

\begin{tabular}{|c|c|c|c|c|c|c|c|c|c|c|c|}
\hline World & $\begin{array}{c}39,8 \\
34\end{array}$ & $\begin{array}{c}49,1 \\
80\end{array}$ & $\begin{array}{c}56,6 \\
97\end{array}$ & $\begin{array}{c}62,1 \\
68\end{array}$ & $\begin{array}{c}64,1 \\
36\end{array}$ & $\begin{array}{c}64,5 \\
23\end{array}$ & $\begin{array}{c}67,5 \\
40\end{array}$ & $\begin{array}{c}69,5 \\
72\end{array}$ & $\begin{array}{c}73,8 \\
92\end{array}$ & $\begin{array}{c}79,1 \\
24\end{array}$ & $\begin{array}{c}80,4 \\
38\end{array}$ \\
\hline YEAR & $\begin{array}{c}\mathbf{2 0 0} \\
\mathbf{9}\end{array}$ & $\mathbf{2 0 1 0}$ & $\mathbf{2 0 1 1}$ & $\mathbf{2 0 1 2}$ & $\mathbf{2 0 1 3}$ & $\begin{array}{c}\mathbf{2 0 1} \\
\mathbf{4}\end{array}$ & $\begin{array}{c}\mathbf{2 0 1} \\
\mathbf{5}\end{array}$ & $\begin{array}{c}\mathbf{2 0 1} \\
\mathbf{6}\end{array}$ & $\begin{array}{c}\mathbf{2 0 1} \\
\mathbf{7}\end{array}$ & $\begin{array}{c}\mathbf{2 0 1} \\
\mathbf{8}\end{array}$ & $\begin{array}{c}\mathbf{2 0 1} \\
\mathbf{9}\end{array}$ \\
\hline $\begin{array}{c}\text { Total priority } \\
\text { territories Group 1 }\end{array}$ & $\begin{array}{c}3,62 \\
8\end{array}$ & $\begin{array}{c}5,03 \\
6\end{array}$ & $\begin{array}{c}5,69 \\
7\end{array}$ & $\begin{array}{c}6,32 \\
8\end{array}$ & $\begin{array}{c}6,80 \\
9\end{array}$ & $\begin{array}{c}5,73 \\
2\end{array}$ & $\begin{array}{c}4,75 \\
8\end{array}$ & $\begin{array}{c}4,82 \\
7\end{array}$ & $\begin{array}{c}5,10 \\
4\end{array}$ & $\begin{array}{c}5,11 \\
2\end{array}$ & $\begin{array}{c}5,59 \\
4\end{array}$ \\
\hline $\begin{array}{c}9.11 \\
\%\end{array}$ & $\begin{array}{c}10.2 \\
4\end{array}$ & $\begin{array}{c}10.0 \\
5 \%\end{array}$ & $\begin{array}{c}10.1 \\
8 \%\end{array}$ & $\begin{array}{c}10.6 \\
2 \%\end{array}$ & $\begin{array}{c}8.88 \\
\%\end{array}$ & $\begin{array}{c}7.04 \\
\%\end{array}$ & $\begin{array}{c}6.94 \\
\%\end{array}$ & $\begin{array}{c}6.91 \\
\%\end{array}$ & $\begin{array}{c}6.46 \\
\%\end{array}$ & $\begin{array}{c}6.95 \\
\%\end{array}$ \\
\hline $\begin{array}{c}\text { Total priority } \\
\text { territories Group 2 }\end{array}$ & 103 & 102 & 129 & 169 & 253 & 229 & 259 & 240 & 247 & 194 & 201 \\
\hline & $\begin{array}{c}0.26 \\
\%\end{array}$ & $\begin{array}{c}0.21 \\
\%\end{array}$ & $\begin{array}{c}0.23 \\
\%\end{array}$ & $\begin{array}{c}0.27 \\
\%\end{array}$ & $\begin{array}{c}0.39 \\
\%\end{array}$ & $\begin{array}{c}0.36 \\
\%\end{array}$ & $\begin{array}{c}0.38 \\
\%\end{array}$ & $\begin{array}{c}0.34 \\
\%\end{array}$ & $\begin{array}{c}0.33 \\
\%\end{array}$ & $\begin{array}{c}0.24 \\
\%\end{array}$ & $\begin{array}{c}0.25 \\
\%\end{array}$ \\
\hline $\begin{array}{c}\text { Total priority } \\
\text { territories } \\
\text { (Group 1 +2) }\end{array}$ & $\begin{array}{c}3,73 \\
1\end{array}$ & $\begin{array}{c}5,13 \\
8\end{array}$ & $\begin{array}{c}5,82 \\
6\end{array}$ & $\begin{array}{c}6,49 \\
7\end{array}$ & $\begin{array}{c}7,06 \\
2\end{array}$ & $\begin{array}{c}5,96 \\
1\end{array}$ & $\begin{array}{c}5,01 \\
8\end{array}$ & $\begin{array}{c}5,06 \\
6\end{array}$ & $\begin{array}{c}5,35 \\
1\end{array}$ & $\begin{array}{c}5,30 \\
6\end{array}$ & $\begin{array}{c}5,79 \\
4\end{array}$ \\
\hline & $\begin{array}{c}9.37 \\
\%\end{array}$ & $\begin{array}{c}10.4 \\
5\end{array}$ & $\begin{array}{c}10.2 \\
8\end{array}$ & $\begin{array}{c}10.4 \\
5 \%\end{array}$ & $\begin{array}{c}11.0 \\
1 \%\end{array}$ & $\begin{array}{c}9.24 \\
\%\end{array}$ & $\begin{array}{c}7.43 \\
\%\end{array}$ & $\begin{array}{c}7.28 \\
\%\end{array}$ & $\begin{array}{c}7.24 \\
\%\end{array}$ & $\begin{array}{c}6.71 \\
\%\end{array}$ & $\begin{array}{c}7.20 \\
\%\end{array}$ \\
\hline
\end{tabular}

Source: authors' calculation based on ITC database (2020)

As can be seen from the table above, third countries' market share on the Slovak export has been decreasing. In 2013, before the implementation period of the new strategy, their share was $11.01 \%$. The most recent data in 2020 reveal massive downturn of the countries' position equal to only $7.20 \%$.

To minimize external shocks (commodity prices, fundamental changes in common commercial policy as well as geopolitical players policy (USA and PRC), authors compared the export results to those of other V4 countries (similar condition, geography, level of economic development). The results can be seen in Table 2: 
Table 2. Comparison of the priority third countries share on total export (V4 export).

\begin{tabular}{|c|c|c|c|c|c|c|c|c|c|c|c|c|}
\hline $\begin{array}{l}\text { PT - } \\
\text { VEV }\end{array}$ & $\begin{array}{l}\text { Priority } \\
\text { territory }\end{array}$ & $\begin{array}{c}200 \\
9\end{array}$ & $\begin{array}{c}201 \\
0\end{array}$ & $\begin{array}{c}201 \\
1\end{array}$ & $\begin{array}{c}201 \\
2\end{array}$ & $\begin{array}{c}201 \\
3\end{array}$ & $\begin{array}{c}201 \\
4\end{array}$ & $\begin{array}{c}201 \\
5\end{array}$ & $\begin{array}{c}201 \\
6 \\
\end{array}$ & $\begin{array}{c}201 \\
7 \\
\end{array}$ & $\begin{array}{c}201 \\
8\end{array}$ & $\begin{array}{c}201 \\
9 \\
\end{array}$ \\
\hline \multirow{3}{*}{ SR } & Group 1 & $\begin{array}{c}9.11 \\
\%\end{array}$ & $\begin{array}{l}10.2 \\
4 \%\end{array}$ & $\begin{array}{l}10.0 \\
5 \%\end{array}$ & $\begin{array}{l}10.1 \\
8 \%\end{array}$ & $\begin{array}{l}10.6 \\
2 \%\end{array}$ & $\begin{array}{c}8.88 \\
\%\end{array}$ & $\begin{array}{c}7.04 \\
\%\end{array}$ & $\begin{array}{c}6.94 \\
\%\end{array}$ & $\begin{array}{c}6.91 \\
\%\end{array}$ & $\begin{array}{c}6.46 \\
\%\end{array}$ & $\begin{array}{c}6.95 \\
\%\end{array}$ \\
\hline & Group 2 & $\begin{array}{c}0.26 \\
\%\end{array}$ & $\begin{array}{c}0.21 \\
\%\end{array}$ & $\begin{array}{c}0.23 \\
\%\end{array}$ & $\begin{array}{c}0.27 \\
\%\end{array}$ & $\begin{array}{c}0.39 \\
\%\end{array}$ & $\begin{array}{c}0.36 \\
\%\end{array}$ & $\begin{array}{c}0.38 \\
\%\end{array}$ & $\begin{array}{c}0.34 \\
\%\end{array}$ & $\begin{array}{c}0.33 \\
\%\end{array}$ & $\begin{array}{c}0.24 \\
\%\end{array}$ & $\begin{array}{c}0.25 \\
\%\end{array}$ \\
\hline & $\begin{array}{c}\text { Total priority } \\
\text { territories }\end{array}$ & $\begin{array}{c}9.37 \\
\%\end{array}$ & $\begin{array}{l}10.4 \\
5 \%\end{array}$ & $\begin{array}{l}10.2 \\
8 \%\end{array}$ & $\begin{array}{l}10.4 \\
5 \%\end{array}$ & $\begin{array}{l}11.0 \\
1 \%\end{array}$ & $\begin{array}{c}9.24 \\
\%\end{array}$ & $\begin{array}{c}7.43 \\
\%\end{array}$ & $\begin{array}{c}7.28 \\
\%\end{array}$ & $\begin{array}{c}7.24 \\
\%\end{array}$ & $\begin{array}{c}6.71 \\
\%\end{array}$ & $\begin{array}{c}7.20 \\
\%\end{array}$ \\
\hline \multirow{3}{*}{$\mathbf{C Z}$} & Group 1 & $\begin{array}{c}6.23 \\
\%\end{array}$ & $\begin{array}{c}7.01 \\
\%\end{array}$ & $\begin{array}{c}7.85 \\
\%\end{array}$ & $\begin{array}{c}9.18 \\
\%\end{array}$ & $\begin{array}{c}9.43 \\
\%\end{array}$ & $\begin{array}{c}8.16 \\
\%\end{array}$ & $\begin{array}{c}6.63 \\
\%\end{array}$ & $\begin{array}{c}6.71 \\
\%\end{array}$ & $\begin{array}{c}6.84 \\
\%\end{array}$ & $\begin{array}{c}6.95 \\
\%\end{array}$ & $\begin{array}{c}7.07 \\
\%\end{array}$ \\
\hline & Group 2 & $\begin{array}{c}1.10 \\
\%\end{array}$ & $\begin{array}{c}0.63 \\
\%\end{array}$ & $\begin{array}{c}0.57 \\
\%\end{array}$ & $\begin{array}{c}0.58 \\
\%\end{array}$ & $\begin{array}{c}0.60 \\
\%\end{array}$ & $\begin{array}{c}0.60 \\
\%\end{array}$ & $\begin{array}{c}0.70 \\
\%\end{array}$ & $\begin{array}{c}0.68 \\
\%\end{array}$ & $\begin{array}{c}0.61 \\
\%\end{array}$ & $\begin{array}{c}0.49 \\
\%\end{array}$ & $\begin{array}{c}0.46 \\
\%\end{array}$ \\
\hline & $\begin{array}{c}\text { Total priority } \\
\text { territories }\end{array}$ & $\begin{array}{c}7.33 \\
\%\end{array}$ & $\begin{array}{c}7.64 \\
\%\end{array}$ & $\begin{array}{c}8.43 \\
\%\end{array}$ & $\begin{array}{c}9.77 \\
\%\end{array}$ & $\begin{array}{l}10.0 \\
4 \%\end{array}$ & $\begin{array}{c}8.76 \\
\%\end{array}$ & $\begin{array}{c}7.33 \\
\%\end{array}$ & $\begin{array}{c}7.39 \\
\%\end{array}$ & $\begin{array}{c}7.44 \\
\%\end{array}$ & $\begin{array}{c}7.44 \\
\%\end{array}$ & $\begin{array}{c}7.53 \\
\%\end{array}$ \\
\hline \multirow{3}{*}{ HU } & Group 1 & $\begin{array}{l}10.8 \\
4 \%\end{array}$ & $\begin{array}{l}12.0 \\
9 \% \\
\end{array}$ & $\begin{array}{l}12.0 \\
4 \%\end{array}$ & $\begin{array}{l}12.5 \\
6 \% \\
\end{array}$ & $\begin{array}{l}12.9 \\
2 \% \\
\end{array}$ & $\begin{array}{l}11.8 \\
7 \% \\
\end{array}$ & $\begin{array}{l}10.3 \\
5 \% \\
\end{array}$ & $\begin{array}{l}10.3 \\
0 \% \\
\end{array}$ & $\begin{array}{l}10.9 \\
0 \% \\
\end{array}$ & $\begin{array}{l}10.1 \\
0 \% \\
\end{array}$ & $\begin{array}{c}9.92 \\
\% \\
\end{array}$ \\
\hline & Group 2 & $\begin{array}{c}1.03 \\
\%\end{array}$ & $\begin{array}{c}1.09 \\
\%\end{array}$ & $\begin{array}{c}1.87 \\
\%\end{array}$ & $\begin{array}{c}1.29 \\
\% \\
\end{array}$ & $\begin{array}{c}1.10 \\
\%\end{array}$ & $\begin{array}{c}0.31 \\
\% \\
\end{array}$ & $\begin{array}{c}0.33 \\
\% \\
\end{array}$ & $\begin{array}{c}0.34 \\
\% \\
\end{array}$ & $\begin{array}{c}0.39 \\
\% \\
\end{array}$ & $\begin{array}{c}0.31 \\
\% \\
\end{array}$ & $\begin{array}{c}0.31 \\
\% \\
\end{array}$ \\
\hline & $\begin{array}{c}\text { Total priority } \\
\text { territories }\end{array}$ & $\begin{array}{l}11.8 \\
7 \%\end{array}$ & $\begin{array}{l}13.1 \\
8 \%\end{array}$ & $\begin{array}{l}13.9 \\
1 \%\end{array}$ & $\begin{array}{l}13.8 \\
5 \%\end{array}$ & $\begin{array}{l}14.0 \\
2 \%\end{array}$ & $\begin{array}{l}12.1 \\
8 \%\end{array}$ & $\begin{array}{l}10.6 \\
8 \%\end{array}$ & $\begin{array}{l}10.6 \\
4 \%\end{array}$ & $\begin{array}{l}11.2 \\
8 \%\end{array}$ & $\begin{array}{l}10.4 \\
1 \%\end{array}$ & $\begin{array}{l}10.2 \\
3 \%\end{array}$ \\
\hline \multirow{3}{*}{ PL } & Gro & $\begin{array}{l}11.0 \\
0 \% \\
\end{array}$ & $\begin{array}{l}11.9 \\
8 \% \\
\end{array}$ & $\begin{array}{l}12.2 \\
8 \% \\
\end{array}$ & $\begin{array}{c}14.1 \\
1 \% \\
\end{array}$ & $\begin{array}{l}13.8 \\
2 \% \\
\end{array}$ & $\begin{array}{l}11.8 \\
3 \% \\
\end{array}$ & $\begin{array}{c}9.84 \\
\% \\
\end{array}$ & $\begin{array}{c}9.97 \\
\% \\
\end{array}$ & $\begin{array}{l}10.3 \\
4 \% \\
\end{array}$ & $\begin{array}{c}9.67 \\
\% \\
\end{array}$ & $\begin{array}{c}9.72 \\
\% \\
\end{array}$ \\
\hline & Group 2 & $\begin{array}{c}0.50 \\
\%\end{array}$ & $\begin{array}{c}0.31 \\
\%\end{array}$ & $\begin{array}{c}0.34 \\
\% \\
\end{array}$ & $\begin{array}{c}0.45 \\
\% \\
\end{array}$ & $\begin{array}{c}0.64 \\
\%\end{array}$ & $\begin{array}{c}077 \\
\%\end{array}$ & $\begin{array}{c}0.65 \\
\%\end{array}$ & $\begin{array}{c}0.51 \\
\%\end{array}$ & $\begin{array}{c}0.45 \\
\%\end{array}$ & $\begin{array}{c}0.37 \\
\%\end{array}$ & $\begin{array}{c}0.55 \\
\%\end{array}$ \\
\hline & $\begin{array}{c}\text { Total priority } \\
\text { territories }\end{array}$ & $\begin{array}{l}11.5 \\
0 \% \\
\end{array}$ & $\begin{array}{l}12.3 \\
0 \% \\
\end{array}$ & $\begin{array}{c}12.6 \\
2 \%\end{array}$ & $\begin{array}{c}14.5 \\
6 \%\end{array}$ & $\begin{array}{c}14.4 \\
6 \% \\
\end{array}$ & $\begin{array}{c}12.6 \\
0 \%\end{array}$ & $\begin{array}{c}10.4 \\
9 \%\end{array}$ & $\begin{array}{l}10.4 \\
8 \% \\
\end{array}$ & $\begin{array}{l}10.7 \\
9 \% \\
\end{array}$ & $\begin{array}{l}10.0 \\
4 \% \\
\end{array}$ & $\begin{array}{c}10.2 \\
7 \% \\
\end{array}$ \\
\hline
\end{tabular}

Source: authors' calculation based on ITC database (2020)

According to Table 2, it can be stated that the territorial interests of the Slovak Strategy of external economic relations we not fulfilled even when reflecting the trend of the territorial changes within the region. Comparing the situation of the Slovak exporters in the researched markets, between 2013 and 2019, their export competitiveness measured by the share on the priority third countries market, decreased by $34.6 \%$. This was much higher number comparing to the Czech Republic, Poland and Hungary $(-25.0 \%,-29.0 \%$ and $-27.0 \%$ respectively). Besides different export stimulation in these countries, regional comparison proves insufficient support schemes for the Slovak exporters, especially from SMEs segment.

Based on procedure to quantify the export gap in the first part, authors tried to identify the export potential for the Slovak companies in the third countries of both priority groups. For this purpose, major export commodity groups were covered: Ores and metals (SITC 27 $+28+68$ ), Non-ferrous metals (SITC 68), Chemical products (SITC 5), Electronic excluding parts and components (SITC 751 $752+761+762+763+775)$, Parts and components for electrical and electronic goods (SITC $759+764+772+776$ ), Other machinery and transport equipment (SITC $7-(751+752+761+762+763+775+759+764+772+776))$, Iron and steel (SITC 67). The results revealed a huge potential of the countries as well as insufficient support mechanism for the Slovak companies in the territories. 
Table 3. Export gap for the Slovak exporters in the priority third countries (mil. \$).

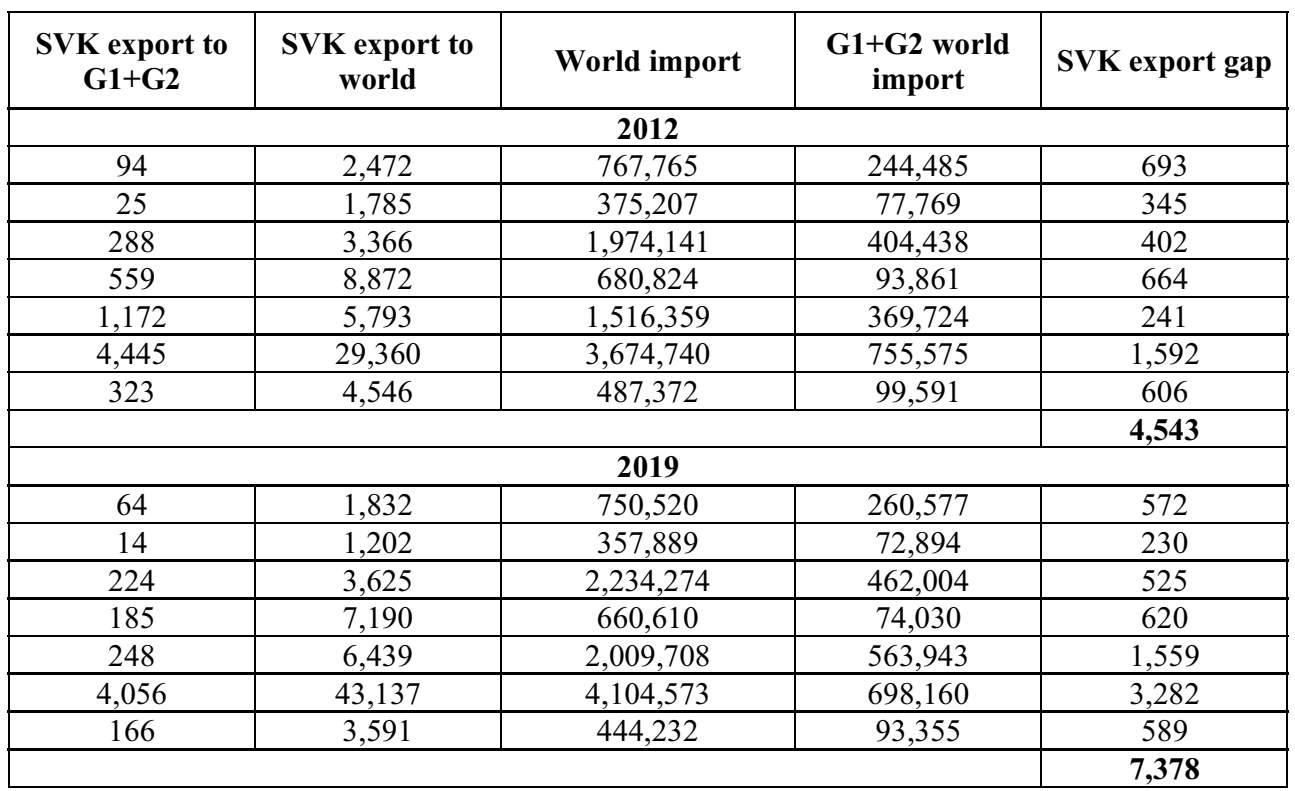

Source: authors calculation based on UNCTAD database (2020)

As can be observed from Table 3, Slovak Strategy of external economic relations has targeted selected third countries appropriately. The export gap on their markets as a potential for the Slovak exporting companies was as much as 4.54 bil. \$. What is even more important, the one of the key research's finding revealing a growing export gap of the Slovak exporters in the targeted third countries. The export gap in 2019 was as much as 7.38 bil. \$ what proves some necessary improvements in the pro-export policy of the Slovak Republic to boost the competitiveness on the markets.

\section{Discussion}

All three approaches indicate insufficient policy related to export competitiveness on the third countries' markets determined by institutional and general economic policy as defined by M. E. Porter [2]. As can be observed directly from the first approach (export dynamics of the Slovak Republic), the share of the priority third countries decreased from $11.01 \%$ in 2013 up to $7.20 \%$ only in 2019. More appropriate and targeted pro-export policy is crucially needed, nevertheless, more possible explanations can affect the territorial structure of the Slovak export within the implementation period. Besides foreign trade restrictions and PTAs of the third countries, currency issues, economic growth as well as foreign market knowledge and market information matters [9]. Based on this assumption, it has been a long-term problematic specific of the Slovak export competitiveness, therefore, we suggest export missions and workshops for the Slovak exporters' foreign department specialists. Moreover, this duty evokes some new requirements for the Slovak SMEs (organizational changes, new management skills [14].

Possible cause of the failure in the Slovak pro-export strategy probably lies to some extent in the huge presence of foreign FDI-based exporters. In connection to a model of their operation (exporting to western European markets), strong orientation and statistically significant export dependence on German GDP could be a possible explanation [1] similar to the effect of the Czech exports [21]. 
Secondly, we consider some crucial commodity market changes as well as sanctions within foreign trade blooming after 2014 to be a serious factor shaping Slovak export territorial structure. Plummeting oil prices from July 2014 in combination with sanctions against steady foreign trade partner (Russian Federation) and subsequent antisanctions caused distinctive volatility as found by Zabojnik and Hricovsky (2017) [23]. Closer look at the partial results proves that, to a large extent, Russia being the second most important Slovak export partner among the monitored countries, decreased its import volume with Slovak by $45 \%$ (2013 to 2019). Very similar effect was recorded in case of Kazakhstan (dramatic export fall by $68 \%$ for the same period). Therefore, we consider crashed oil prices (2014) and sanctions against Russia (since 2014) to be an important factor standing behind the unfulfilled objectives of the strategy in some territories.

From a wider perspective, further recommendations for the V4 countries have been formulated recently to boost export competitiveness. The recommendations stress key measures in the economic policy to improve participation of the V4 countries within GVCs mainly via innovation policy improvements. Otherwise, exportation to the third countries from Slovakia will be only intermediated and direct exporters with the highest margin will be the countries possessing the headquarters of the TNCs present in Slovakia (Germany, South Korea, Netherlands, France etc.).

\section{Conclusion}

Assessing almost the whole implementation period for the objectives of the Slovak Strategy of the External Economic Relations, more parameters were not fulfilled. The main purpose of the article was to identify the export competitiveness of the Slovak exporters on the third countries' markets. To assess the territorial transformation of the Slovak export, we found no positive results. The share of the countries of priority interest defined as the key export markets with adequate support and financial tools, has not been increased and relevant objectives were not fulfilled. Moreover, their share on Slovak exports decreased from 11.01 $\%$ in 2012 to $7.20 \%$ in 2019. One possible explanation is a worse position of Russia (and also Kazakhstan) in the Slovak export due to EU sanctions applied in 2014 and economic downturn of the Russian economy stemming from commodity prices fall after July 2014. Systematic approach stimulating export competitiveness of the Slovak SMEs has to be applied.

Based on this finding, we recommend vast changes in the structure of the export strategy tools and export incentives in the Slovak Republic. Important question is if this kind of changes are necessary for the economic development since literature brought ambiguous findings. Another possible pillar of the new strategy could lie in the maximization of the added value within Slovak export. Therefore, major focus of the export policy has to be adjusted by higher participation within GVCs. According to our findings, necessary changes have to be implemented to support economic diplomacy for the SMEs and especially for their activities on the markets of the developing countries and specific territories.

This paper is a part of a research project of the Ministry of Education, Family and Sports of the Slovak Republic VEGA (in the period 2020 - 2022) No. 1/0777/20: Belt and Road initiative - opportunity or threat for the EU and Slovak export competitiveness?

\section{References}

1. Balaz, P., Hamara, A. (2016). Analýza závislosti exportu SR na vývoji ekonomiky SRN. Politická Ekonomie: Teorie, Modelování, Aplikace, 64(5), 573-590. 
2. Balaz, P., Hamara, A., Sopkova, G. (2015). Konkurencieschopnost' a jej význam v národnej ekonomike: (zmeny a zvýzvy v obdobi globálnej finančnej krízy). Bratislava: Sprint.2

3. Balaz, P., Zabojnik, S., Skorvagova, S., Kittova, Z., Sterbova, L., Kastakova, E., Minarik, M., Pavelka, L., Drienikova, K. (2019). Medzinárodné podnikanie. Bratislava: Sprint 2.

4. Benkovskis, K., Rimgailaite, R. (2011). The quality and variety of exports from the new EU member states. Economics of Transition, 19(4), 723-747.

5. Benkovskis, K., Bluhm, B., Bobeica, E., Osbat, C., Zeugner, S. (2020). What drives export market shares? It depends! An empirical analysis using Bayesian model averaging. Empirical Economics, 59(2), 817-869.

6. Bojnec, S., Fertő, I. (2014). Export competitiveness of dairy products on global markets: The case of the European Union countries. Journal of Dairy Science, 97(10), 6151-6163.

7. Broncek, J. (2019). China's economic growth through the lens of cobb-douglas production function - An ARDL Approach. In MEKON 2019. International Conference. MEKON 2019: Proceedings of the 21st International Conference (pp. 2634). Ostrava : Technical University of Ostrava.

8. Carrasco, C. A., Tovar-García, E. D. (2020). Trade and growth in developing countries: The role of export composition, import composition and export diversification. Economic Change and Restructuring.

9. Cieślik, J., Kaciak, E., Thongpapanl, N. (T.). (2015). Effect of export experience and market scope strategy on export performance: Evidence from Poland. International Business Review, 24(5), 772-780.

10. del Rosal, I. (2019). Export Diversification and Export Performance by Destination Country. Bulletin of Economic Research, 71(1), 58-74.

11. Fojtikova, L. (2014). Performance and growth of the eurozone export. Procedia Economics and Finance, 12, 154-163.

12. Fojtakova, L. (2016). Trends in the revealed comparative advantages of the EU member states. Economic Annals-XXI, 161(9-10), 7-11.

13. Fojtikova, L., Stanickova, M. (2017). The EU member states export competitiveness and productivity. Politická Ekonomie: Teorie, Modelování, Aplikace, 65(6), 669-689.

14. Guillou, S., Treibich, T. (2019). Firm export diversification and change in workforce composition. Review of World Economics, 155(4), 645-676.

15. Hajiha, A., Zamani, L., Saeednia, H. R. (2009). The influence of export experience and export information use on export knowledge and performance. 2009 IEEE International Conference on Industrial Engineering and Engineering Management (pp. 26-30). Hong Kong: IEEE.

16. ITC (2019). Trade map. Retrieved from: https://www.trademap.org/Index.aspx.

17. Majerova, I. (2014). Export performance and transformational performance as measurable indicators of macroeconomic competitiveness regarding selected EU Countries and Switzerland. Proceedings of the 2st International Conference on European Integration 2014 (pp. 439-447). Ostrava: VŠB - Technical University of Ostrava.

18. Ruzekova, V., Kastakova, E. (2018). Comparison of the Visegrad group and Baltic countries in terms of multi-criteria competitiveness indicators. Studia Commercialia 
Bratislavensia Scientific Journal of Faculty of Commerce, University of Economics in Bratislava, 11(1), 91-106.

19. Sevela, M. (2019). Export vulnerability of Central European countries. IBIMA 2019: proceedings of the 33rd international business information management association conference (pp.10-11). Granada: IBIMA.

20. Sterbova, L. et al. (2013). Mezinárodní obchod ve světové krizy 21. století. Praha: Grada.

21. Tauser, J., Arltova, M., Zambersky, P. (2015). Czech exports and German GDP: A closer look. Prague Economic Papers, 24(1), 17-37.

22. UNCTAD. (2020). Trade trends database. UNCTADstat. Retrieved from: https://unctadstat.unctad.org/wds/ReportFolders/reportFolders.aspx.

23. Zabojnik, S., Hricovsky, M. (2017). Foreign trade bans against Russia and its consequences. Globalization and its socio-economic consequences: proceedings: 17th international scientific conference (pp. 3022-3029). Zilina: University of Zilina. 